\title{
A Memorial Tribute
}

\section{Peter Barnes: the Playwright who Laughed at Death}

\begin{abstract}
The death on 1 July 2004 of the playwright Peter Barnes robbed the British theatre of one of its most individual and richly imaginative yet shamefully neglected writers. Although his best known work for the theatre - which included The Ruling Classes, The Bewitched, Laughter, Red Noses, and Dreaming - won widespread admiration, and his later radio and television work brought him before a wider public, he remained a theatrical outsider, his plays transcending the conventions of critical labels and movements - the singe discernible influence that of Ben Jonson, whose eccentric genius he championed throughout his life. Here we include three personal tributes: the oration delivered at Barnes's funeral by the stage and screen actor Alan Rickman; recollections from the avant-garde director Charles Marowitz of his association with Barnes's early career at the Traverse and his own Open Space Theatre in the 'sixties; and the impressions of a personal friend, the lecturer and writer Elaine Turner. An analytical assessent of Peter Barnes's work will appear in a later issue.
\end{abstract}

DOI: $10.1017 / \mathrm{SO266464X04210193}$

\section{Alan Rickman}

\section{Lighting the Storm}

ACTORS loved Peter.

Peter loved actors. Especially if their skill also gave them a fast track to the odd bit of inspired lunacy. It was mutual recognition.

One of his favourite actors - one of the finest and one of the maddest - was Peter Bayliss. When Peter Bayliss died it became known that he wished for no great ceremony. On the contrary, he wished for his remains to be flushed down a lavatory. His friends couldn't quite go there, but with great organizational flair, and to the delight of Peter Barnes, Jonathan Butterell borrowed a toilet bowl from the props department of the National Theatre, we took it to the stage of the Open Air Theatre in Regents Park, stood in a circle and solemnly poured water onto the ashes down - as it were - the toilet. The moment the last drop drained, an aged cycle messenger in purple and green Lycra with helmet and goggles came down the aisle yelling, 'Is anyone here connected to the theatre?'
We looked at each other in silent and awed acknowledgement. The spirit of Peter Bayliss had returned to tell us the game was up.

I mention this because I'm not entirely sure where Peter Barnes stood on the subject of the afterlife, but I know this experience brought forth endless chortling. Peter is, after all, the man who wrote:

For thirty years, I've been trying to light the storm with mirrors, whirlpools, balloons, moonglow, and starbursts.

So it is with some confidence that I picture him shooting the breeze, as we speak, with Peter Bayliss. And Marlon Brando ...

Peter also wrote this about himself: 'I've made a mess of my life, but then I've made a mess of my shirts.' It is absolutely true about the shirts, but not true at all about the life neither as a writer nor as a man.

I think it was always hard for Peter to measure his own worth. Partly because, as Paul Marcus said to me, he was Peter the Heretic, the visionary outsider - constantly being discovered by the Establishment and then cast out - and partly because his collaborators and critics could only rarely match 
his soaring, even (as Stephen Deutsch said) promiscuous imagination.

Strange how I hear echoes of Peter everywhere just now. The other evening I watched Vivienne Westwood - another genius and anarchist - speaking on film. She said, 'People call me arrogant. I'm quite comfortable with my arrogance. I see my work as a statement against the mediocrity all around me.' Or as Peter put it:

Some voices are charmers and other voices we are instinctively against. On many occasions we can't analyze why we have this reaction. I think any artist must speak with his own voice and then accept the fact that it is going to divide people.

Greg Doran directed Peter's play Jubilee at the RSC and writes:

The play was a hit with audiences not least for the scene when David Garrick has a nightmare in which Peter Hall, Terry Hands and Trevor Nunn all appear to persuade him he must do the Jubilee or they will be out of a job in the future. But the play was not such a hit with the critics who may possibly have objected to this description by a critic of his job: 'a profession which is respectable, malicious and utterly irrelevant except to those poor folk who've no opinions of their own.'

But in dividing people along the way, Peter was also gathering an enormous and devoted following. Perhaps especially amongst actors. His writing forced you to work from instinct; and then, of course, there were always the jokes. Nicholas Woodeson writes from New York:

One day, rehearsing Jubilee in Stratford, we were leaving the rehearsal room. Things had got to the stage when it seemed that I was the only other human being involved in the enterprise who had any idea what he was on about. I'd mentioned that I'd lived, as a little Christian kid, in Israel. He said, 'Um, I've just got this joke - you know I'm Jewish don't you? - well, um, er, um ...', and continuing in that deceptively bumbling and innocent delivery, 'this man wins the lottery and throws a party to celebrate and leads his guests into the dining room and there, on the wall, in the place of honour, is this full-length portrait of Hitler. Eventually someone asks, "Er, what's that doing there?" He says, "Well I had it commissioned especially, because I owe it all to him, he gave me the lucky number tattooed on my arm."'

Andrew Seear, an actor friend of Nicholas's, recalled seeing Frontiers of Farce at the Old Vic, starring Leonard Rossiter and adapted by Peter. In one relentlessly funny sequence involving multiple bedpans, Andrew was in such pain from laughing that he had to look away from the stage for fear of serious injury.

What was so funny? What was his joke we were trying to tell? Same as always - the abyss yawning its head off at your feet, while you struggle with the monster that is trying to push you in. I think, as writer and actors, that is the tie that bound us.

Peter the writer was one of the people who shaped my working life. Fresh from drama school, I sat open-mouthed at the Aldwych watching The Bewitched and wanting it to go on for ever. Later, I worked with Peter and Stuart Burge on The Devil is an Ass, and from then on almost whenever he asked. I have dressed as an Amazon, flown across the stage one foot in a rope, and made an entrance on my back crawling head first to the front of the stage. Professionally, I was hooked.

Personally, it has been my privilege to have known him as a friend. First Peter, then Peter and Charlotte, then Peter and Christie, then Peter, Christie, Leela, Abigail, Nathaniel, and Zachary. And I have seen the joy he had as husband and father.

A mess of his life? No. But how do you measure your own humanity, vulnerability, loyalty, clumsiness, love of life's absurdities? These are qualities Peter had in abundance. It was for $u$ s to know them and love him for them. I measure Peter not just from the challenge of working with him and his amazing words, but also from the lunches we shared in the Pizza Express where he would rail Lear-like against the storm. Or the breakfast we once had in a very greasy spoon where, with the greatest generosity, he immeasurably improved my lines in a film script with a mixture of pencil and fried egg yolk. 


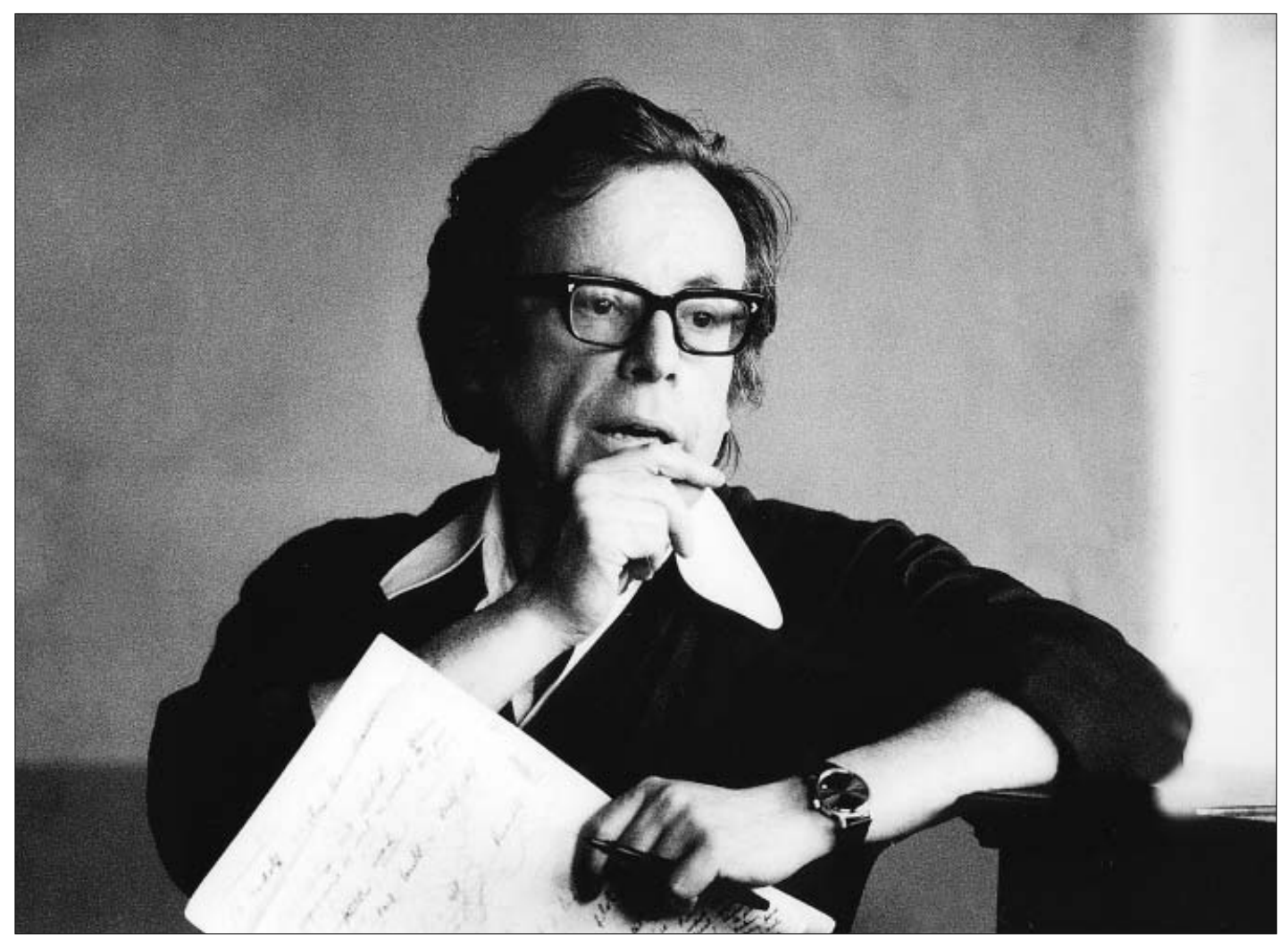

But then his methods were always unconventional.

Peter Medak (who directed the film of The Ruling Class) talks of finding Peter at work in the Reading Room of the British Museum in the early 'sixties (before he graduated to writing in the Leicester Square branch of McDonald's) surrounded by books, his face one and a half inches from the desk, glasses on his forehead, scribbling on the backs of old scripts. They would then dash off to lunch at the Gay Hussar or follow a troupe of buskers - the Happy Wanderers - around the London streets after watching Godard, Truffaut, Buñuel, Fellini, Resnais, and Renoir.

Says Peter: 'I often used to pick him up in my Mini from rehearsals or performances of The Ruling Class at the Piccadilly Theatre and take him home to the Edgware Road where he lived above a Laundromat. On the final performance of The Ruling Class, I could barely get him into the car as he insisted on taking home the model of the House of Lords. As we drove away from the theatre a single tear rolled down his face.'
Peter Medak speaks for us all when he says: 'My love goes out to Christie, to all the children and to you, Peter, you Happy Wanderer.'

In Revolutionary Witness Peter gave a voice to Jacques Roux - a preacher in the French Revolution - but these final words are in essence the voice of Peter Barnes: a man who made the most profound gift of himself to his work, his friends, and his family all his life. A man whose legacy we should celebrate and cherish.

And so amen. If it's to be the last amen I go gladly. My wife and son will weep, I know, and Georges my dog here will howl a little, won't you, boy? Friends will pause and shake their heads and move on. For they have the difficult part. Living well is so much harder than dying well. They'll remain whilst mad Jacques Roux will become at worst a footnote in history. I haven't done anything bad enough to be included in the main text.

I've tried to help create a people who are sceptical, rational, critical, not easily fooled or impressed. In a word, a free people - ungovern- 
able! It's a dream of course, but I've been lucky to have lived through times that made the dream seem possible, when for a moment we stopped being me and mine, you and yours, us and them, and saw ourselves instead as equals in our common humanity. We are of that generation that so transformed the world that future days and nights can never be the same. We poor clumsy men and women turned the world upside down, inside out, round and about.

One last word from my last sermon. The Revolution isn't complete, hardly begun. Defend it. Don't sit back - act! Without action no life, without life no perfection, without perfection no eternal peace and freedom. For God is an active power so we do his work in fighting the great battles, light against darkness, love against selfishness, revolution against reaction, life against death. Come on, Georges, it's time for our walk.

DOI: 10.1017/SO266464X0422019x

\section{Charles Marowitz}

\section{The Unforgettable Maverick}

PETER BARNES was one of the first writers I met when I arrived in London in the late 'fifties and the one with whom I forged the strongest ties. He and his first wife Charlotte went out constantly on double dates with Gillian Watt and me, mostly to movies which Peter ruthlessly demolished in coffee-klatches afterwards - all screenwriters and playwrights in a diabolical conspiracy to foist rubbish and keep his works from public view.

Peggy Ramsay had sent me a copy of Sclerosis, which, during a period of pathological Artaud-worship, struck me as the only contemporary play I had read which truly captured the spirit of Theatre of Cruelty. This was long before my collaboration with Peter Brook during the Theatre of Cruelty season at the RSC, and long before Artaud emerged from the shadows as an intriguing theorist and pervasive theatrical influence. I directed the play at the Traverse in Edinburgh, and then for a Sunday-night performance at the
Aldwych, the first Peter Barnes play to be professionally staged in England. It was given a rough ride by some veterans in the audience who took it to be a slur against the British occupation army in Cyprus. Peter's works were always offending somebody or other.

In those days, he wrote scorching little plays animated by malice and spite in which comedy and cruelty would regularly copulate. They revealed a palsied, Jonsonian view of humanity without a smidgen of sentimentality and were usually unredeemed by warmth or sympathy. They were usually crudely funny, but even when they weren't funny the crudeness had a lively Rabelaisian zest about it which made you snicker even when it didn't make you laugh. Peter adored Ben Jonson and the sprit of that cynical old curmudgeon informed all of his best work.

When I directed Laughter at the Royal Court, there was the same backwash of revulsion. Jokes about Auschwitz and the concentration camps? Really, there has to be some limit even to bad taste! But of course, with Peter there never was. Once his humour got right down to the bone, it started drilling through the calcium.

For some years, I tried to interest managements in Clap Hands Here Comes Charlie, an assault on patronizing middle-class attitudes towards the poor, exemplified by an altruistic couple who adopt a homeless drifter with disastrous results for one and all. It got as far as being optioned by an American producer and talks with Jason Robards in Hollywood, but ultimately unravelled; again the general consensus seemed to be that it oozed 'bad taste'. I did present a staged reading of the play in Malibu some years back and affluent members of the community, mirror-images of the respectable couple who took in the vagrant Charlie, expressed their disgust to me in letters and phone calls. 'Not a proper play for the Malibu community,' I was told, and they were probably right although anything deeper than Charlie's Aunt would have failed there by the same measure.

I was supposed to direct The Ruling Class for Stuart Burge in Nottingham. I'd been with the play since its inception and even edited an early version for production but, 
when it came to pass, it clashed with the transfer of Fortune and Men's Eyes from the Open Space to the Comedy, and it was simply impossible to do both at the same time. I don't think Peter ever entirely forgave me for opting for Fortune, but it was the first West End transfer for the Open Space and my loyalties had to lie there. We had a rapprochement soon afterwards when I directed Leonardo's Last Supper and Noonday Demons, two short, bitter plays of Peter's presented at the Open Space.

Peter Barnes was probably the most brilliant anti-social playwright England produced in the last quarter of the twentieth century. By 'anti-social' I mean a writer who never bought into the genteel value-system that was swallowed whole by most of his contemporaries. He was fed up with a cruel kind of Britishness which corrupted politics and revelled in a sort of laissez-faire morality. The world, as he saw it, was full of chisellers and con-men, hypocrites and grifters who were either ludicrous or malevolent or both. His cynicism was bred in the bone, and so cunningly that he could defer it at will and appear to be a member of the moral majority when the occasion arose. He was ruthlessly honest and honestly outraged by mendacity. It was a taste that took some getting used to - and many in England did not have the stomach to acquire it.

DOI: $10.1017 / \mathrm{SO266464 \times 04230196}$

\section{Elaine Turner}

\section{The Power of Dreams}

SKELTON: So move on, life is a journey. DAVY: Life is a race. RESS: No, life is a dance.

PETER BARNES's life was a gift: his boisterous and thrilling plays, his directing, his critical essays, his parties, his friendship, his family. He can hardly be separated from his work. Most of his large family of friends amassed somehow from his plays: performers, directors, affectionados like myself.
Peter was a wonderful friend. Generous and loyal, even to the past. He felt an obligation to Ben Jonson and a love of his works which he expressed by never turning down an opportunity to promote Jonson and his works. He thought of himself as a Jacobean, and although some of his friends would argue 'Elizabethan', Peter had the immense breadth of learning and vision that characterizes the Jacobeans and their innate quest for the bringing together of diversity.

Being one of Peter's friends was a privilege and a treat. He was endlessly encouraging and generous. Diana Fairfax tells how they were once discussing her desire to direct, when he opened a cupboard, took out a handful of short plays, and said, 'Have these.' The result was a successful Barnes evening at the Tristan Bates Theatre. He happily encouraged an ex-student of mine in her dream of adapting his fabulous TV adaptation of The Arabian Nights for the stage.

We met over twenty years ago when I was using my lectures in Contemporary British Theatre at Warwick to meet the playwrights I admired. Despite the long journey, poor remuneration, and worries about public speaking, Peter met me at Euston. We travelled to and from the University together, and the friendship grew in a gradual sort of way, through discussions about his work and the nature of theatre, film, and TV, the occasional Chinese meal, and, eventually, the miracle of children. Peter and I also shared a deeply unfashionable love of London. Peter and his wife Christie lit up my life.

And who shall we tell jokes to now? And who will tell us the oddball, strangely dark but insightful jokes which Peter so enthusiastically collected, setting our view of life askew?

Recently, Peter and I were writing entries for the Continuum Encyclopaedia of British Literature - he on Ben Jonson and other Jacobeans; me on Peter Barnes. I asked him if there was anything he wanted me to address. 'Yes,' he said. 'No one has written about the spiritual nature of my work.' His plays have justly been called 'epic'; they address social and political issues, historical and philosophical concerns, often through large-scale action, 


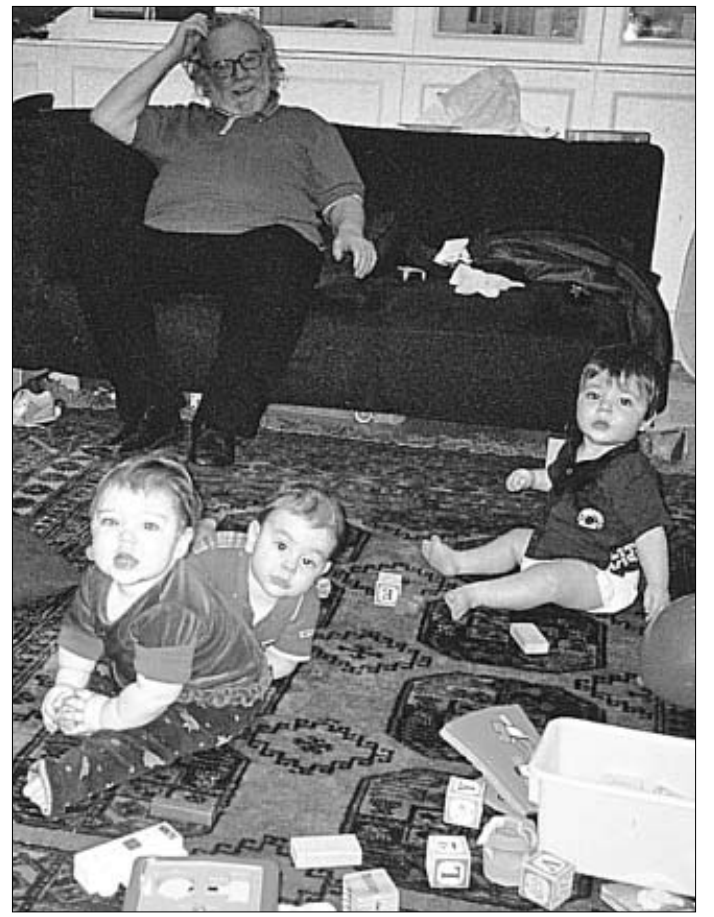

cast, and time-span. At the same time, spiritual issues beat at the heart of each one: the function of religion in everyday life; the dynamics of faith; the place of spirit in the material world. In his masterpiece, Red Noses, Peter pulled off the most extraordinary of stylistic coups - a 'rough', populist style replete with slapstick and music-hall joke-telling which culminates in a powerful manifestation of spirit, a genuine metaphysical experience.

Peter's passion was for theatre and pure entertainment and the love of life. Although he found recognition and success writing for cinema and $\mathrm{TV}$, for him it was theatre and only theatre that really mattered.

When he first started writing for TV, he complained bitterly about its limitations, its flatness, its confinement; and the necessities of media and form became a constant topic of discussion: 'Make it do what you want it to do.' Peter could not prevent himself from writing thought-provoking and entertaining work, but the TV breakthrough came with his astonishing version of Dickens's Hard Times: not the familiar illustrated narrative, but an evocation of the emotional and philosophical dynamics of the novel through highly theatrical, visual moments.
There was no stopping him. He treated television like a playground, with the clear, dynamic plot frolicking magically through ever-increasing flights of imagination. (Did you see the faucet in Aladdin's sky?) Despite his increasing freedom and success in television, theatre was the jewel of his heart. He loved the expanse of it, the pleasure of it, the scope for invention as well as its wealth of history. Peter insisted: only his theatre work was to be taken seriously.

The essence of the man is the essence of the work: Peter's deep sympathy for each individual life and his unwavering faith in the power of dreams. He spoke of his own work with insight and humility. Each play seemed to take interminable years to find its way to the stage - Peter reckoned an average of eight years; and the puzzling and unconscionable lack of recognition of his work clearly upset him. But he never became bitter. Recently he noted the irony that he had received more attention as a seventy-twoyear-old father of triplets than he had in all his years as a playwright.

His marriage to Christie, the acquiring of terrier Fox, their daughter Leela, and finally the triplets turned Peter's last years into pure happiness. It was a privilege to be asked to be a godmother to a triplet. The sudden increase in the Barnes population filled the little mews house with energy and warmth - with Peter, bemused and delighted, surrounded by tiny, loving bodies.

There will never be a new, anarchic, compassionate, thought-provoking and heartthrilling Peter Barnes play. A dear, unique friend has left us behind.

Peter Barnes gave us a rare combination of innocence and wisdom. His life and his works stand as precious examples of a truth so essential but so easy to forget: 'The triumph of hope over experience.'

Goodbye, dear friend. Our lives have been blessed by your presence.

To whose dear memory I this tribute send Who dead's my wonder, living was my friend.

John Beaumont on the death of his friend Ben Jonson 